Jurnal Ilmu Hukum Reusam

ISSN 2302-6219 E-ISSN 27225100

Volume VIII Nomor 2 (November 2020)

Fakultas Hukum Universitas Malikussaleh universitas MALIKUSSALEH

The Blessing University

\title{
PENGGANTIAN BIAYA KEPADA SAKSI ATAU AHLI DALAM RANGKA MEMBERIKAN KETERANGAN DALAM SISTEM PERADILAN PIDANA (Studi Penelitian di Wilayah Hukum Pengadilan Negeri Takengon)
}

\author{
Lisa Hajini Purba ${ }^{1}$, Sumiadi², Yusrizal $^{3}$ \\ Email : sumiadi@unima.ac.id \\ ${ }^{1}$ Alumni Fakulas Hukum Universitas Malikussaleh \\ ${ }^{23}$ Dosen Fakultas Hukum Universitas Malikussaleh
}

\begin{abstract}
Summons of witnesses at each level of criminal case examination has consequences for the cost of attending the summons. So far, the provisions regarding the cost of summoning witnesses and experts have been regulated in Article 229 of the Criminal Procedure Code and Law Number 13 of 2006 concerning Protection of Witnesses and Victims and Law Number 2 of 2002 concerning Procedures for Protection of Witnesses and Victims in Human rights violations, however, in reality the fees that have been regulated in the law are not fully provided to all witnesses and even if there are costs they are not up to standard and not optimal. These costs include accommodation costs, consumption costs, transportation costs and costs of reimbursing lost income due to having to attend calls. The purpose of this research is to find out and explain the compensation mechanism to witnesses or experts in order to differentiate information in the criminal justice system in the jurisdiction of the Takengon District Court and what are the obstacles in reimbursing costs to witnesses or experts in order to provide information in the criminal justice system in the region. the law of the Takengon District Court. This type of research is juridical empirical, that is, approaching the problem through legal research by looking at the prevailing legal norms and relating them to the facts that exist in society in connection with the problems encountered in the research. The results showed that the cost reimbursement mechanism for witnesses or experts in order to provide information at the police level, namely starting with budget proposals, the Central Aceh Police proposed a budget through an index on other operational items. The index is available only for very difficult and difficult cases while there is no index for easy cases. The reason for this is the limited budget in the police index. Reimbursement for witnesses or experts at the prosecutor's level did not work properly, because the budget included in the Prosecutor's DIPA was inadequate, such as for consumption, transportation and accommodation costs. So that often the prosecutor's office bears the cost. Reimbursement for witnesses or experts at court. Level was never given because the authorities to summon and examine witnesses were the police and the prosecutor's office. The court is only tasked with adjudicating criminal cases. Constraints for reimbursement of fees to witnesses or experts in the context of providing information in the criminal justice system in the jurisdiction of the Takengon District Court, namely the limited police budget, inadequate budget at the prosecutor's office, no further regulation regarding how much fees should be paid to witnesses. It is hoped that law enforcement officials should implement and submit budgets in the Police index and in the DIPA of the Attorney General's Office and the application of witness rights can be further enhanced and maximized, in order to guarantee the protection of witnesses' rights. The government also needs to provide a balance regarding reimbursement of expenses to witnesses in order to achieve a sense of justice in the implementation at every level of the criminal case examination process, because basically a witness has the right to receive reimbursement in accordance with Article 229 of the Criminal Procedure Code and the Law. Number 13 of 2006 concerning Protection of Witnesses and Victims.
\end{abstract}

Key Words: Reimbursement, Witness or Expert, Criminal Justice System 


\section{A. PENDAHUluan}

Keterangan saksi merupakan bukti yang paling penting, artinya keterangan saksi dalam setiap proses pemeriksaan perkara pidana tetap diperlukan walaupun pembuktian dengan alat bukti lain telah ada dan telah dilakukan. "Tidak ada perkara pidana yang luput dari pembuktian dengan alat bukti keterangan saksi dan hampir semua pembuktian perkara pidana selalu bersandar kepada pemeriksaan keterangan saksi".

Keberadaan saksi dalam suatu proses peradilan pidana mulai dari tahap penyelidikan, penyidikan, penuntutan hingga persidangan di pengadilan dalam rangka memberikan keterangan

sesuai dengan yang ia dengar sendiri, ia lihat sendiri, dan ia alami sendiri untuk mengungkap fakta atas terjadinya suatu tindak pidana memiliki resiko tersendiri. Berbagai ancaman baik secara mental maupun fisik akan selalu hadir seiring dengan adanya kaitan berbagai pihak dengan kasus-kasus yang diperiksa. Hal ini haruslah mendapat perhatian sesuai dengan perkembangan hukum yang sangat memerlukan seorang saksi dalam hal pengungkapan suatu perkara.

Namun dalam kenyataannya bahwa saksi yang dipanggil di tingat penyidikan, penuntutan maupun persidangan tidak semuanya mendapatkan penggantian biaya dan kalaupun ada biaya. tersebut tidak sesuai dengan standar dan tidak optimal diberikan. Hal ini tentu saja merugikan saksi karena hak-haknya tidak diberikan, padahal ia rela mengorbankan waktu serta harus mengeluarkan biaya lagi akibat memenuhi panggilan tersebut. Seharusnya segala sesuatu yang telah diundangkan harus dijalankan karena itu merupakan perintah Negara dan segala sesuatu yang diperintahkan Negara pasti memiliki dasar dan dana namun kenapa dalam hal pelaksaan Pasal 229 Kitab UndangUndang Hukum Acara Pidana tidak berjalan seperti yang diamanatkan oleh KUHAP tersebut. Apabila perintah di dalam Undang-Undang dapat terlaksana dengan baik

maka tentunya semua saksi akan mendapatkan haknya dan tidak ada lagi kategori-kategori tertentu yang mendapatkan penggantian biaya tersebut. Berdasarkan latar belakang masalah yang telah diuraikan di atas, maka perlu dilakukan kajian lebih lanjut tentang Penggantian Biaya Kepada Saksi Atau Ahli Dalam Rangka Memberikan Keterangan Dalam Sistem Peradilan Pidana (Studi Penelitian Di Wilayah Hukum Pengadilan Negeri Takengon). Untuk melihat bagaimana mekanisme penggantian biaya kepada saksi atau ahli dalam rangka memberikan keterangan dalam sistem peradilan pidana di wilayah hukum Pengadilan Negeri Takengon serta bagaimana 
pelaksanaan penggantian biaya kepada saksi atau ahli dalam rangka memberikan keterangan dalam sistem peradilan pidana di wilayah hukum Pengadilan Negeri Takengon.

\section{B. METODE PENELITIAN}

Jenis penelitian ini adalah yuridis empiris, yaitu pendekatan masalah melalui penelitian hukum dengan melihat norma hukum yang berlaku dan menghubungkan dengan fakta yang ada dalam masyarakat sehubungan dengan permasalahan yang ditemui dalam penelitian. pendekatan yang digunakan dalam penelitian ini adalah pendekatan yuridis sosiologis. Pendekatan yuridis sosiologis adalah Mengidentifikasi dan mengkonsepsikan hukum sebagai institusi sosial yang riil dan fungsional dalam sistem kehidupan yang nyata. Pendekatan yuridis sosiologis adalah menekankan penelitian yang bertujuan memperoleh pengetahuan hukum secara empiris dengan jalan terjun langsung ke objeknya yaitu mengetahui penggantian biaya kepada saksi atau ahli dalam rangka memberikan keterangan dalam sistem peradilan pidana. Pendekatan perundang-undangan (Statute Approach) dilakukan dengan menelaah semua regulasi atau peraturan perundang-undangan yang bersangkutan dengan isu hukum yang akan diteliti mengenai penggantian biaya kepada saksi atau ahli dalam rangka memberikan keterangan dalam sistem peradilan pidana sesuai dengan Pasal 229 Kitab Undang-Undang Hukum Acara Pidana (KUHAP).

\section{PEMBAHASAN}

1. Mekanisme Penggantian Biaya Kepada Saksi Atau Ahli Dalam Rangka Memberikan Keterangan Dalam Sistem Peradilan Pidana di Wilayah Hukum Pengadilan Negeri Takengon

Peranan seorang saksi dalam setiap persidangan perkara pidana sangat penting karena keterangan saksi dapat mempengaruhi dan menentukan kecenderungan keputusan hakim. Seorang saksi dianggap memiliki kemampuan yang dapat menentukan kemana arah putusan hakim. Hal ini memberikan efek kepada setiap keterangan saksi sebagai salah satu alat bukti berdasarkan Pasal 184 Kitab Undang-Undang Hukum Acara Pidana, sehingga selalu mendapat perhatian yang sangat besar baik dari pelaku hukum yang terlibat di dalam persidangan maupun oleh masyarakat pemerhati hukum. Oleh karena itu, saksi sudah sepatutnya diberikan perlindungan hukum karena dalam mengungkap suatu tindak pidana saksi secara sadar mengambil resiko dalam mengungkap kebenaran materil.

Pasal 229 Kitab UndangUndang Hukum Acara Pidana (KUHAP) menjelaskan bahwa saksi mempunyai hak untuk mendapatkan 
penggantian biaya atas kehadirannya di sidang pengadilan, sebagaimana dijelaskan sebagai berikut:

(1) Saksi atau ahli yang telah hadir memenuhi panggilan dalam rangka memberikan keterangan di semua tingkat pemeriksaan, berhak mendapatkan penggantian biaya menurut peraturan perundang-undangan.

(2) Pejabat yang melakuk an pemanggilan wajib memberitahuk an kepada saksi atau ahli tentang haknya sebagimana dimaksud dalam ayat (1).

Undang-

Undang Nomor 13 Tahun 2006 tenta ng Perlindungan Saksi dan Korban menjelaskan bahwa Saksi harus memperoleh perlindungan atas keamanan pribadi, keluarga, dan harta bendanya serta bebas dari ancaman yang berkenaan dengan kesaksiannya yang akan, sedang, atau telah diberikannya. Selanjutnya saksi berhak untuk memperoleh penggantian biaya transportasi sesuai dengan kebutuhan, memperoleh penggantian biaya hidup sementara sampai batas waktu perlindungan berakhir, serta berhak untuk ikut serta dalam proses memilih dan menentukan bentuk perlindungan dan dukungan keamaan.

Namun dalam kenyataannya hal tersebut tidak sepenuhnya terlaksana dengan baik dikarenakan tidak semua saksi memperoleh penggantian biaya. Adapun saksi yang diberikan penggantian biaya tersebut hanyalah kepada saksi-saksi dalam kasus tertentu yang tingkat penanganannya sangat sulit dan sulit contohnya seperti kasus pembunuhan, kasus korupsi dan kasus lainnya. Sedangkan saksi untuk kasus yang tingkat penangannya dikategorikan mudah seperti kasus pencurian tidak mendapatkan penggantian biaya dan kalaupun ada diberikan itu lebih ke inisiatif pihak kepolisian. Adapun penyebab tidak diberikannya biaya kepada saksi yang dikategorikan tingkat penangannya mudah, karena anggaran yang tersedia di kepolisian terbatas sehingga pihak kepolisian tidak bisa memberikan penggantian biaya kepada semua saksi yang hadir memenuhi panggilan.

Berdasarkan hal tersebut di atas, penggantian biaya kepada saksi di tingkat kepolisian dalam prakteknya masih belum sepenuhnya terlaksana dengan baik sesuai dengan apa yang diamanatkan di dalam Pasal 229 Kitab Undang-Undang Hukum Acara Pidana. Mengenai hal tersebut adanya perbedaan perlakuan yang dilakukan oleh aparat penegak hukum dalam melakukan pemanggilan saksi, artinya pemanggilan saksi yang dilakukan oleh pihak kepolisian tidak diimbangi dengan hak bagi seseorang yang dipanggil baik sebagai saksi. bagaimanapun juga seseorang yang dipanggil untuk menghadap, maka seseorang tersebut 
pasti telah mengorbankan waktu dalam hal ini yang bersangkutan rela meninggalkan pekerjaannya dan bahkan ia harus mengeluarkan biaya lagi untuk datang memenuhi panggilan tersebut. Hal inilah yang sangat penting untuk di perbaiki atau di benahi dan harus menjadi perhatian khusus bagi para pihak yang berwenang karena merekalah yang berkompeten terkait dengan masalah hak-hak saksi.

Sedangkan anggaran untuk seorang ahli ada di indeks kepolisian, mengenai besaran penggantian biaya yang diterima ahli tergantung seperti apa tingkat kesulitan kasus-kasus yang mereka tangani. setelah selesai memberikan keterangannya seorang ahli mendapatkan penggantian biaya konsumsi, transportasi dan biaya kehilangan penghasilannya di hari itu. Seorang ahli merasa haknya sudah terpenuhi dan ia tidak merasa dirugikan.

Sudah menjadi kewajiban Negara untuk memberikan penggantian biaya kepada saksi atau ahli melalui lembaga penegak hukum yang diberi kewenangan untuk memanggil saksi atau ahli tersebut. Karena pada dasarnya, pihak yang paling memiliki kepentingan dalam penegakkan hukum adalah Negara karena hukumnya dilanggar. Oleh karena itu jika disandarkan pada siapa yang berkepentingan maka ia yang harus mengganti biaya, dalam hal ini maka Negara lah yang wajib menggantinya.
2. Kendala Dalam Penggantian Biaya Kepada Saksi Atau Ahli Di Wilayah Hukum Pengadilan Negeri Takengon

Mengingat betapa pentingnya kedudukan dan peranan saksi dalam pengungkapan kebenaran dalam perkara pidana, sudah saatnya semua para saksi diberikan penggantian biaya berupa biaya konsumsi, biaya akomodasi, biaya transportasi dan biaya pengganti pendapatan yang hilang sebagaimana yang diamanatkan dalam Pasal 229 Kitab Undang-Undang Hukum Acara Pidana. Adanya perbedaan perlakuan dan ketidakseimbangan terhadap pemenuhan hak-hak saksi akan membuat para saksi menjadi enggan memberikan kesaksiannya di muka pengadilan bahkan kadang kala sama sekali tidak mengaku bahwa ia melihat dan mengetahui tentang tindak pidana tersebut padahal ia adalah saksi kunci yang dapat menjelaskan mengenai tindak pidana yang terjadi.

Adapun kendala dalam pelaksanaan Pasal 229 Kitab Undang-Undang Hukum Acara Pidana tentang penggantian biaya kepada saksi di wilayah hukum Pengadilan Negeri Takengon sebagai berikut:

1. Anggaran di kepolisian terbatas

Suatu sistem akan berjalan secara optimal jika semua objek yang diperlukan saling mendukung. 
Selama ini banyak anggapan yang muncul bahwa alasan mengenaiterbatasnya anggaran merupakan faktor utama yang menyebabkan hak saksi tidak bisa terpenuhi secara maksimal. Masalah keuangan merupakan bagian permasalahan yang harus dihadapi oleh pihak kepolisian untuk melakukan pemenuhan hak penggantian biaya pada saksi di wilayah hukum Pengadilan Negeri Takengon. Karena banyaknya kasus yang ditangani, mulai dari kasus tindak pidana umum maupun kasus tindak pidana khusus, sehingga menyebabkan tidak semua saksi mendapatkan penggantian biaya tersebut. Akibat keterbatasan biaya, banyak hak saksi yang dilalaikan ataupun tampak terpinggirkan karena disebabkan kurangnya dana yang mendukung agar hak saksi itu terpenuhi.

\section{Anggaran di DIPA kejaksaan tidak memadai}

Anggaran untuk penggantian biaya saksi atau ahli memang sudah diatur di DIPA kejaksaan, akan tetapi tidak memadai, dikarenakan jumlah saksi maupun ahli yang dihadirkan kadang kala melebihi dari kapasitas yang ditentukan di anggaran DIPA tersebut. Dalam setahun perkara yang masuk tidak hanya satu kadang sampai 3 perkara. Hal itu tentu saja menjadi kendala bagi pihak kejaksaan karena dengan dana yang tidak memadai tersebut, seringkali pihak kejaksaan yang menanggung kekurangan dananya.

Zainul Arifin, (Kepala Seksi

Tindak Pidana Khusus Kejaksaan Negeri Takengon), mengungkapkan bahwa dengan biaya Rp. 400.000.(empat ratus ribu rupiah) tersebut tidak mencukupi atau memadai untuk mengadirkan saksi terutama bagi saksi tindak pidana khusus, karena biaya transportasinya jauh lebih besar dibandingkan dengan saksi tindak pidana umum. Sehingga mau tidak mau pihak kejaksaanlah yang menanggungnya karena menghadirkan saksi adalah kewajiban jaksa.

3. Tidak adanya aturan khusus Pasal 229 Kitab UndangUndang Hukum Acara Pidana dan Undang-Undang Nomor 13 Tahun 2006 tentang Perlindungan Saksi dan Korban sudah mengatur mengenai penggantian biaya saksi. Namun Undang-Undang tersebut tidak menjelaskan mengenai berapa besar biaya yang harus diberikan kepada saksi sehingga menjadi salah satu kendala dalam hal pelaksanaanya. Seharusnya pemerintah membuat aturan khusus tentang berapa besar biaya yang harus diterima saksi seperti halnya ahli yang biayanya sudah diatur dalam Peraturan Menteri Keuangan. 


\section{KESIMPULAN}

Berdasarkan uraian dan hasil analisis yang telah dilakukan maka dapat ditarik kesimpulan dari hasil penelitian ini diantaranya : Mekanisme penggantian biaya kepada saksi atau ahli dalam rangka memberikan keterangan di tingkat Kepolisian yaitu di awali dengan penggusulan anggaran, pihak Polres Aceh Tengah mengusulkan anggaran melaui indeks pada item belanja barang operasional lainnya. Indeks yang tersedia hanya untuk perkara sangat sulit dan sulit sedangkan untuk perkara mudah tidak ada. Penyebabnya karena keterbatasan anggaran di indeks kepolisian. Penggantian biaya saksi atau ahli di tingkat Kejaksaan tidak berjalan sebagaimana mestinya, karena anggaran yang masuk di DIPA Kejaksaan tidak memadai, seperti untuk biaya konsumsi, transpotasi, akomodasinya tidak mencukupi. Sehingga sering kali pihak kejaksaan yang menanggung kekurangan biaya tersebut. Penggantian biaya saksi atau ahli di tingkat Pengadilan tidak pernah diberikan karena yang berwenang memanggil dan memeriksa saksi adalah pihak Kepolisian dan Kejaksaan, Pengadilan hanya bertugas untuk mengadili perkara tindak pidana.

Kendala penggantian biaya kepada saksi atau ahli dalam rangka memberikan keterangan dalam sistem peradilan pidana di wilayah hukum Pengadilan Negeri Takengon yaitu anggaran di kepolisian terbatas, anggaran di Kejaksaan kurang memadai, tidak adanya aturan yang mengatur lebih lanjut tentang berapa besar biaya yang harus diberikan kepada saksi.

\section{Saran}

1. Pemerintah perlu menambahkan dana anggaran pos operasional aparat penegak hukum khususnya yang menangani pembiayaan terhadap saksi atau ahli yang dihadirkan untuk memberikan keterangan dalam proses perkara pidana sesuai dengan ketentuan Padal 229 Kitab Undang-Undang Hukum Acara Pidana Serta penerapan terhadap hak saksi dapat lebih ditingkatkan dan dimaksimalkan lagi, agar menjamin perlindungan terhadap hak-hak saksi.

2. Aparat penegak hukum harus melaksanakan ketentuan dari Pasal 229 Kitab Undang-Undang Hukum Acara Pidana dan Undang-Undang Nomor 13 Tahun 2006 tentang perlindungan Saksi dan Korban di wilayah hukum Pengadilan Negeri Takengon dan harus memberikan keseimbangan mengenai penggantian biaya kepada saksi demi tercapainya rasa keadilan dalam pelaksanaan di semua tingkatan serta memberitahukan tentang hakhak terhadap saksi yang 
dihadirkan dalam setiap tingkat proses pemeriksaan perkara pidana.

\section{DAFTAR PUSTAKA}

Chazawi, Adami. 2006. Hukum PembuktianTindak Pidana Korupsi, Alumni, Bandung.

Faal, M. 1987. Penyaringan Perkara Pidana Oleh Polisi (Diskresi Kepolisian). Pradnya Paramita, Jakarta.

Hamzah, Andi. 1996. Hukum Acara Pidana Indonesia, Sapta Artha Jaya, Jakarta. . 2006. Kitab UndangUndang Hukum Acara Pidana, Rineka Cipta, Jakarta.

Harahap, M. Yahya. 2002. Pembahasan Permasalahan dan Penerapan KUHAP, Sinar Grafika, Jakarta.

................. . 2004. Pembahasan Permasalahan dan Penerapan KUHAP, Penyidikan dan Penuntutan, Edisi Kedua, Sinar Grafika.

Karim, A. Nasution. 1976. Masalah Hukum Pembuktian dalam Proses Pidana, I, Papas Sinar Sinanti, Jakarta.

Marpaung, Leden. 1997. Proses Tuntutan Ganti Kerugian Dan Rehabilitasi Dalam Hukum Pidana, PT. Raja Grafindo Persada, Jakarta.
M, Marwan dan Jimmy. 2009. Kamus Hukum, Reality Publisher, Surabaya.

Muhadar. 2009. Perlindungan Saksi dan Korban Dalam Sistem Peradilan Pidana, ITS. Press, Surabaya.

Pohan, Agustinus dan Topo Santoso, 2012. Hukum Pidana Dalam Perspektif, Pustaka Larasan, Denpasar.

Poerwadarminta, W.J.S. 1976. Kamus Umum Bahasa Indonesia, Balai Pustaka, Jakarta.

Prakoso, Djoko. 2003. Alat Bukti dan Kekuatan Pembuktian di Dalam Proses Pidana, Liberty, Yogyakarta.

Pradjodikoro, Wiryono. 1977. Hukum Acara Pidana, Sumur, Bandung.

Reksodiputro, Marjdono. 1993. Sistem Peradilan Pidana Indonesia (Melihat Kepada Kejatan Dan Penegakan Hukum Dalam Batas Batas Toleransi), Fakultas Hukum Universitas Indonesia.

Soemitro, Ronny Hanitijo. 1998. Metode Penelitian Hukum dan Jumetri, Ghalia Indonesia, Jakarta.

Suggono, Bambang. 2000. Metode Penelitian Hukum, PT. Raja Grafindo Persada, Jakarta.

Soekanto, $\quad$ Soerjono. 1984. Pengantar Penelitian Hukum, UI Press, Jakarta. 
Tanusubroto, S. 1989. Dasar-Dasar Hukum Acara Pidana Cetakan 2, armico, bandung.

Zulkarnain, 2013. Praktik Peradilan

Pidana, Setara Pres, Indonesia. 